\title{
An inter-comparison of Arctic synoptic scale storms between four global reanalysis datasets
}

\author{
Alexander F. Vessey ${ }^{1}$ (i) $\cdot$ Kevin I. Hodges ${ }^{1,3} \cdot$ Len C. Shaffrey ${ }^{1,3} \cdot$ Jonathan J. Day $^{2}$
}

Received: 24 June 2019 / Accepted: 24 January 2020 / Published online: 12 February 2020

(c) The Author(s) 2020

\begin{abstract}
The Arctic is becoming more accessible as sea ice extent continues to decline, resulting in higher human exposure to Arctic storms. This study compares Arctic storm characteristics between the ECMWF-Interim Reanalysis, 55-year Japanese Reanalysis, NASA-Modern Era Retrospective Analysis for Research and Applications Version 2 and National Centre for Environmental Prediction-Climate Forecast System Reanalysis datasets between 1980 and 2017, in winter (DJF) and summer (JJA). It is shown that Arctic storm characteristics are sensitive to the variable used for storm tracking. Arctic storm frequency is found to be similar in summer and winter when using sea level pressure minima to track Arctic storms, whereas, the storm frequency is found to be higher in winter than summer when using $850 \mathrm{hPa}$ relative vorticity to track storms, based on using the same storm tracking algorithm. It is also found that there are no significant trends in Arctic storm characteristics between 1980 and 2017. Given the sparsity of observations in the Arctic, it might be expected that there are large differences in Arctic storm characteristics between the reanalysis datasets. Though, some similar Arctic storm characteristics are found between the reanalysis datasets, it is found that the differences in Arctic storm characteristics between the reanalysis datasets are generally higher in winter than in summer. Overall, the results show that there are differences in Arctic storm characteristics between reanalysis datasets, but even larger differences can arise between using $850 \mathrm{hPa}$ relative vorticity or mean sea level pressure as the storm tracking variable, which adds to the uncertainty associated with current Arctic storm characteristics.
\end{abstract}

Keywords Arctic storms · Reanalysis datasets

\section{Introduction}

The Arctic is currently undergoing rapid change. Arctic sea ice extent has reduced dramatically over recent decades in both its maximum and minimum extent (National Snow \& Ice Data Centre 2019). Climate model projections indicate that sea ice extent will continue to reduce in summer and winter, with a sea ice-free Arctic expected to occur in

Electronic supplementary material The online version of this article (https://doi.org/10.1007/s00382-020-05142-4) contains supplementary material, which is available to authorized users.

Alexander F. Vessey

alexander.vessey@pgr.reading.ac.uk

1 Department of Meteorology, University of Reading, Earley Gate, Reading RG6 6BB, UK

2 ECMWF, Shinfield Park, Reading RG2 9AX, UK

3 National Centre for Atmospheric Science, University of Reading, Earley Gate, Reading RG6 6BB, UK summer in the near future (Wang and Overland 2012; Flake 2013; Petrick et al. 2017). As a consequence of the decline in sea ice, human activity in the Arctic (such as oil exploration, shipping and tourism) is increasing (Melia et al. 2016). Increased human activity will also result in an increase in exposure to hazardous weather conditions, such as the strong winds and waves associated with Arctic synopticscale storms. To assess the risks associated with increased exposure it is therefore important to determine the characteristics of Arctic storms. One way to assess Arctic storm risk is to use atmospheric reanalyses, which are created by assimilating observations into numerical atmospheric models. Reanalyses provide both spatial and temporal homogeneous datasets, which is particularly important in the poorly observed Arctic. However, the sparseness of conventional observations, conservative use of lower tropospheric satellite data over sea ice, snow and low-level cloud covered areas, and high background model error in polar regions, could lead to larger differences between reanalyses in the Arctic, 
compared to mid-latitudes (Bauer et al. 2016; Jung et al. 2016; Lawrence et al. 2019).

Earlier studies of Arctic storm characteristics focused on analysing individual reanalyses. For example, using the National Centers for Environmental Prediction (NCEP)-National Centre for Atmospheric Research (NCAR) reanalysis, Zhang et al. (2004) and Sorteberg and Walsh (2008) found that Arctic storms reach a lower central mean sea level pressure (MSLP) and higher relative vorticity in winter than in summer, and that Arctic storms have longer duration in summer than in winter. Recent studies have compared multiple reanalysis datasets to assess the uncertainty of Arctic storm characteristics (Tilinina et al. 2014; Zahn et al. 2018). Tilinina et al. (2014) found that the number of Arctic storms was dependent on the resolution of the reanalysis, with the higher resolution Arctic System Reanalysis dataset (ASR) having a higher number of weaker storms or mesoscale storms than the lower resolution European Centre for Medium-Range Weather Forecasts (ECMWF) Interim Reanalysis (ERA-Interim), National Aeronautics and Space Administration (NASA) Modern Era Retrospective Analysis for Research and Applications (MERRA) and NCEP Climate Forecast System Reanalysis (NCEP-CFSR) datasets.

Differences in the trends of Arctic storm frequency have also been found in atmospheric reanalyses. Sorteberg and Walsh (2008) and Sepp and Jaagus (2011) found that Arctic storm frequency increased between 1949 and 2002 in the NCEP-NCAR reanalysis dataset, especially for summer. However, results using more recent reanalysis datasets such as the ECMWF-40 year Reanalysis dataset (ERA-40), found that Arctic storm frequency had not changed (Simmonds et al. 2008; Serreze and Barrett 2008). Similarly, Zahn et al. (2018) also assessed a range of different reanalyses, but did not find any substantial trends over the period studied (1981-2010). The above differences found between reanalyses highlights the continuing need to evaluate and understand the uncertainty in Arctic storm characteristics in the reanalyses, especially as they are often used as a baseline for evaluating climate models (Vavrus 2013; Day et al. 2018).

One robust feature seen in reanalyses is that the location of Arctic storm tracks appear to be seasonally dependent (Reed and Kunkel 1960; Serreze et al. 2001; Simmonds et al. 2008; Crawford and Serreze 2016). The main summer storm track tends to be strongest over Eurasia and into the central Arctic Ocean. The region of storm genesis over coastal continental Eurasia and the Arctic Ocean in summer has been referred to as the Arctic Frontal Zone, and results from the strong temperature gradient between the snow-free land and ocean (Reed and Kunkel 1960; Serreze et al. 2001; Simmonds et al. 2008; Crawford and Serreze 2015; Day and Hodges 2018). In winter, the storm track predominantly occurs in the Greenland, Norwegian and Barents Seas. Synoptic-scale Arctic storms in winter often have their genesis in the mid-latitudes and travel polewards into the Arctic (Hodges et al. 2011). One key question is whether the differences between storms in the reanalyses are predominately associated with those that have genesis in the Arctic, where reanalyses may be poorly constrained by the sparse observational network.

Another topic addressed in previous studies is the seasonal cycle of Arctic storm frequency. A number of papers using MSLP as the storm tracking variable found that Arctic synoptic-scale storm frequency was higher in summer than in winter (Serreze 1995; Serreze et al. 2001; Tilinina et al. 2014; Zahn et al. 2018). In contrast, Simmonds et al. (2008) found that Arctic synoptic-scale storm frequency was higher in winter than in summer in the ERA-40, NCEP-NCAR and NCEP-Department of Energy (DOE) reanalysis datasets, using the laplacian of pressure (geostrophic vorticity) as the tracking variable. One possibility for these different results is the assumptions made in the storm tracking algorithm in terms of storm identification, tracking and filtering, for example the number of storms identified within reanalyses is dependent on the choice of storm tracking algorithm (Neu et al. 2013). One of the main differences between methods are whether storms are identified using MSLP minima or lower tropospheric vorticity maxima. Hodges et al. (2011) and Jung et al. (2012) showed that the number of storms identified is higher for a storm tracking algorithm that is based on $850 \mathrm{hPa}$ relative vorticity field rather than the MSLP. This is primarily because smaller spatial scales are present in vorticity compared to MSLP (Hoskins and Hodges 2002). Arctic storm characteristics have typically been assessed using storm tracking algorithms based on MSLP (Serreze 1995; Zhang et al. 2004; Simmonds et al. 2008; Tilinina et al. 2014; Crawford and Serreze 2016; Zahn et al. 2018), which raises questions regarding the sensitivity of the choice of identification variable.

This paper aims to improve our understanding of the Arctic synoptic scale storms by assessing their characteristics in multiple global reanalyses. This will be achieved by the following objectives:

- Determine whether there are any trends in Arctic storm activity from 1980 to 2017 for winter (DJF) and summer (JJA) in the ERA-Interim, JRA-55, MERRA-2 and NCEP-CFSR reanalyses.

- Assess the frequency, spatial distribution and intensity of synoptic-scale Arctic storms.

- Determine whether the differences in Arctic storm characteristics between reanalyses are associated with storms that have their genesis in mid-latitude regions or the Arctic.

- Determine the sensitivity of Arctic storm characteristics to the storm tracking identification variable using relative vorticity and MSLP. 
In Sect. 2 a description of the data and methodology used to identify and compare Arctic storms in each reanalysis dataset is given. Section 3 presents the climatological and inter-annual variability in Arctic storm frequency between each reanalysis dataset. Section 4 describes the spatial distribution of Arctic storms in terms of track density and genesis density and the difference between each reanalysis dataset. Section 5 compares the intensity of Arctic storms between each reanalysis dataset. Section 6 presents results from storm track matching analysis between reanalysis datasets. Arctic storms identified using the different tracking variables (i.e. relative vorticity or MSLP) are compared in Sect. 7. A summary and conclusions are given in Sect. 8.

\section{Methodology}

\subsection{Reanalysis datasets}

This study compares Arctic storms identified in data from the ERA-Interim (Dee et al. 2011), JRA-55 (Kobayashi et al. 2015), MERRA-2 (Gelaro et al. 2017) and NCEPCFSR (Saha et al. 2014) reanalysis datasets. A comparison is made between winter (DJF) and summer (JJA) for a common time period, 1980-2017. In this study, data from the 6 hour analyses are used for each of the datasets. Each of the four reanalysis datasets are created by different institutions, using different numerical weather prediction (NWP) models and data assimilation systems.

\section{a. ERA-Interim}

ERA-Interim is produced by the European Centre for Medium Range Weather Forecasts (ECMWF). Data is created using the Integrated Forecasting System version Cy31r2 model, which is a spectral model (Dee et al. 2011). ERAInterim has a horizontal resolution of $0.75^{\circ} \times 0.75^{\circ}$ and a vertical resolution of 60 levels up to $0.1 \mathrm{hPa}$ (T255 spectral resolution, L60). Historical observations are quality controlled, bias corrected, and assimilated using a 4D-Variational system, which adjusts model projections to observations both forward and backward in time.

\section{b. JRA-55}

The 55-year Japanese Reanalysis (JRA-55) has been produced by the Japanese Meteorological Agency (JMA) and was created using the JMA Global Spectral Model (GSM). JRA-55 has a higher horizontal resolution than ERAInterim; $0.55^{\circ} \times 0.55^{\circ}$ (T319 spectral resolution), and has the same vertical resolution of 60 levels up to $0.1 \mathrm{hPa}$ (L60) (Kobayashi et al. 2015). However, the relative vorticity, wind and MSLP data is provided at a reduced horizontal resolution of $1.25^{\circ} \times 1.25^{\circ}$. Like ERA-Interim, historical observations are quality controlled and bias corrected and assimilated into the JMA GSM using a 4D-Variational system.

\section{c. MERRA-2}

Unlike ERA-Interim and JRA-55, MERRA-2 is created using a Grid-Point model; the Goddard Earth Observing System model from the National Aeronautics Space Association (NASA) (Gelaro et al. 2017). MERRA-2 has a higher horizontal and vertical resolution than ERA-Interim and JRA-55 of $0.625^{\circ} \times 0.5^{\circ}$ and 72 levels up to $0.01 \mathrm{hPa}$. Past observations are assimilated using a 3D-Variational system, which only adjusts model projections forward in time.

\section{d. NCEP-CFSR}

Unlike the other reanalysis datasets, NCEP-CFSR was created using a coupled atmosphere-ocean model, from the National Centers for Environmental Prediction (NCEP) (Saha et al. 2010). The atmosphere component is derived from the Climate Forecast System (CFS), which is coupled to the Modular Ocean Model version 4. Similar to ERAInterim and JRA-55, NCEP-CFSR was created using a spectral model. NCEP-CFSR has the highest resolution of all the reanalysis datasets compared in this study, with a horizontal resolution of $0.5^{\circ} \times 0.5^{\circ}$ and vertical resolution of 64 levels up to $0.3 \mathrm{hPa}$ (T382 spectral resolution, L64). Historical observations were assimilated into the CFS model using a 3D-Variational system, similar to MERRA-2.

\subsection{Arctic storm tracking}

There are many storm tracking algorithms available (Neu et al. 2013). In this study, storms were identified from the reanalysis datasets using the objective storm tracking algorithm developed by Hodges (1994, 1995, 1999). This tracking algorithm has been widely used to track storms in climate and NWP studies (Hodges et al. 2011; Zappa et al. 2013; Day et al. 2018). In this study, a comparison is performed between storms identified using the two different identification variables of $850 \mathrm{hPa}$ relative vorticity and MSLP. Typically, tracking algorithms based on the $850 \mathrm{hPa}$ relative vorticity field are able to identify smaller scale systems than is the case for MSLP at the same resolution. Vorticity based algorithms are also less influenced by the background flow than MSLP, which can mask synoptic scale systems until they develop sufficiently (Sinclair 1994). The $850 \mathrm{hPa}$ relative vorticity field is also not extrapolated over regions of high orography. In this study, Arctic storms are first identified based on tracking with $850 \mathrm{hPa}$ relative vorticity rather than 
MSLP, as storms generally have smaller radius at higher latitudes (Simmonds 2000; Rudeva and Gulev 2007), and relative vorticity based algorithms tend to identify smaller scale storms better than MSLP based algorithms (Neu et al. 2013).

The data from each reanalysis dataset is first regridded onto a similar grid to allow for a fair comparison. In this study, data from each reanalysis dataset has been interpolated onto the ERA-Interim grid, as it is the lowest resolution grid of all the reanalysis datasets $\left(0.75^{\circ} \times 0.75^{\circ}\right)$. Before performing the tracking, the field of choice is first spectrally filtered to remove the planetary scales for total wavenumbers less than or equal to 5 , to focus on systems independent of large-scale forcings. The resolution of the $850 \mathrm{hPa}$ relative vorticity and MSLP fields are decreased to $\mathrm{T} 42$ and $\mathrm{T} 63$ resolution, respectively, to reduce noise within the field and ensure that the tracking algorithm identifies the main circulation of storms and not smallscale features within the storm. The T42 and T63 spectral filters were chosen to focus on synoptic scale storms, whereas, higher resolution filters are typically used to analyse meso-scale phenomena such as polar lows (Zappa et al. 2014; Tous et al. 2016). The different filters for vorticity and MSLP are due to MSLP being a much smoother field and more influenced by the large scale background.

The storms are first identified at each 6 hour timestep in each reanalysis dataset as maxima in the $850 \mathrm{hPa}$ relative vorticity above a threshold of $1.0 \times 10^{-5} \mathrm{~s}^{-1}$ and minima in MSLP. The tracks are initialised based on a nearest-neighbour method and then refined by minimising a cost function. Once the storms have been tracked in either field, the tracks are filtered to retain those that last more than 2 days and travel more than $1000 \mathrm{~km}$, so that the focus is on the synoptic scale and mobile storms. Following the tracking, additional fields are added to the tracks; the full resolution $925 \mathrm{hPa}$ wind speed maxima and the MSLP minima. The additional fields are added by searching for the maximum wind speed within a $6^{\circ}$ radius of the tracked center and by identifying the closest pressure minima withing a $5^{\circ}$ radius. These additional fields are added to give a more relatable measure of the intensity of a storm, rather than $850 \mathrm{hPa}$ relative vorticity maxima at $\mathrm{T} 42$ spectral resolution.

In previous studies, different domains have been used to define the Arctic. In this study, Arctic storms are defined as storms that travel north of $65^{\circ} \mathrm{N}$, so that storms that have genesis over inland continental Eurasia, as identified by (Crawford and Serreze 2016), are included. A distinction between Arctic storms with Arctic genesis (north of $65^{\circ} \mathrm{N}$ ) and mid-latitude genesis (south of $65^{\circ} \mathrm{N}$ and travel north of $65^{\circ} \mathrm{N}$ ) is also made.

\subsection{How Arctic storm characteristics are calculated}

In this study, the number of storms per season, the spatial distribution, and the intensity of Arctic storms are identified and compared between the four reanalysis datasets. Arctic storm frequency is calculated by counting the number of storms per season that travel north of $65^{\circ} \mathrm{N}$. The spatial distribution statistics of Arctic storms are calculated using the spherical kernel approach (Hodges 1996). The spatial statistics of track density and genesis density are highlighted to show the geographical distribution of storms across the Arctic and how this may differ between the reanalysis datasets. The statistical significance of the spatial distribution differences between the reanalysis datasets are tested using a Monte Carlo significance test (Hodges 2008). To quantify the intensity of Arctic storms, the maximum intensity distributions of Arctic storms from each reanalysis dataset have been constructed for the $925 \mathrm{hPa}$ wind field and the MSLP field, to quantify the impact of Arctic storms at the surface and how this may differ between reanalysis dataset. For Arctic storms with mid-latitude genesis, the maximum intensity has been taken once they are in the Arctic. The $925 \mathrm{hPa}$ wind speed field are compared instead of the 10-metre wind speed field as they are specifically calculated by each model, whereas, 10-metre wind speeds are a diagnostic extrapolated from the lowest model level. To directly compare the storm tracks between the reanalysis datasets, a storm matching analysis has been performed (Hodges et al. 2011). The same storm is matched between two reanalysis datasets by finding the storm tracks that have a minimum mean separation distance of less than $4^{\circ}$ (geodesic), and that overlap in time by at least $50 \%$ of the points in their life cycle. To gauge how similarly Arctic storms are represented in reanalyses to mid-latitude storms, a comparison is made by matching midlatitude storms between the datasets; mid-latitude storms are defined as storms that have genesis between $35^{\circ} \mathrm{N}$ and $65^{\circ} \mathrm{N}$.

\section{Arctic storm frequency}

\subsection{Climatological Arctic storm frequency}

Using the storm tracking based on the $\mathrm{T} 42850 \mathrm{hPa}$ relative vorticity, it has been found that Arctic storms occur with a frequency of more than 1 storm per day in both winter and summer (see Table 1). Storm frequency is higher in winter than in summer in every reanalysis dataset. The reanalyses show that on average, 116 storms per season occur in winter and 97 storms per season occur in summer, with the frequency per season in winter and summer being similar between the reanalyses (see Table 1). The percentage of Arctic storms with Arctic or mid-latitude genesis is also consistent across the reanalysis datasets (see Table 1). In winter and 
Table 1 Frequency of all Arctic storms that travel north of $65^{\circ} \mathrm{N}$ and the percentage with Arctic (north of $65^{\circ} \mathrm{N}$ ) or mid-latitude genesis (south of $65^{\circ} \mathrm{N}$ ) in winter (DJF) and summer (JJA) between ERA-
Interim, JRA-55, MERRA-2 and NCEP-CFSR, for the period of 1980/81-2016/17 in winter and 1980-2017 in summer

\begin{tabular}{|c|c|c|c|c|c|c|}
\hline & \multicolumn{3}{|c|}{$\begin{array}{l}\text { Winter (DJF) (1980/81-2016/17) } \\
\text { (per season) }\end{array}$} & \multicolumn{3}{|c|}{$\begin{array}{l}\text { Summer (JJA) (1980-2017) } \\
\text { (per season) }\end{array}$} \\
\hline & $\begin{array}{l}\text { Total number of } \\
\text { Arctic storms }\end{array}$ & $\begin{array}{l}\% \text { of total with } \\
\text { Arctic gen- } \\
\text { esis }(\%)\end{array}$ & $\begin{array}{l}\% \text { of total with mid- } \\
\text { latitude genesis }(\%)\end{array}$ & $\begin{array}{l}\text { Total number of } \\
\text { Arctic storms }\end{array}$ & $\begin{array}{l}\% \text { of total with } \\
\text { Arctic genesis (\%) }\end{array}$ & $\begin{array}{l}\% \text { of total with } \\
\text { mid-latitude gen- } \\
\text { esis (\%) }\end{array}$ \\
\hline ERA-Interim & 119.4 & 54.0 & 46.0 & 98.3 & 47.1 & 52.9 \\
\hline JRA-55 & 116.3 & 55.3 & 44.7 & 96.4 & 47.0 & 53.0 \\
\hline MERRA-2 & 113.7 & 53.4 & 46.6 & 96.2 & 47.6 & 52.4 \\
\hline NCEP-CFSR & 115.6 & 54.9 & 45.1 & 96.6 & 47.8 & 52.2 \\
\hline Average & 116.3 & 54.4 & 45.6 & 96.9 & 47.4 & 52.6 \\
\hline
\end{tabular}

summer, approximately $50 \%$ of all Arctic storms have midlatitude genesis. This indicates that there are a considerable amount of Arctic storms with mid-latitude genesis, which may transport air from low to high latitudes.

Overall, ERA-Interim has the highest number of Arctic storms per season in both winter (119.4) and summer (98.3) than the other reanalyses, whereas, MERRA-2 has the lowest number of storms per season in winter (113.7) and in summer (96.2) compared with the other reanalyses. The range of the differences in storm frequency per season between the reanalysis datasets is higher in winter than in summer, 5.7 and 2.1 storms per season, respectively. Thus, in winter, there is less agreement in Arctic storm frequency per season between the datasets. The frequency of Arctic storms shown in Table 1 is lower than was found in Tilinina et al. (2014) and Zahn et al. (2018), likely due to filtering the storms to stricter criteria on lifetime and distance travelled in this study.

Arctic storm frequency is found to be higher in winter than in summer, which is contrary to previous studies (Serreze 1995; Serreze et al. 2001; Tilinina et al. 2014; Zahn et al. 2018), that used storm tracking algorithms based on MSLP minima to identify Arctic storms within reanalysis datasets, instead of $850 \mathrm{hPa}$ relative vorticity used in this study. MSLP based storm tracking algorithms identify fewer small-scale storms than vorticity based algorithms (Neu et al. 2013). Thus Table 1 may include more small scale storms than were identified in previous studies. Simmonds et al. (2008) used a storm tracking algorithm based on the Laplacian of pressure (geostrophic vorticity) rather than minima in MSLP, and also found storm frequency per season to be higher in winter than summer. Simmonds et al. (2008) found that in winter, there are more 'open strong' storms, which are not associated with a closed MSLP minima. As a result, these storms would not be identified by storm tracking algorithms based on MSLP minima.

\subsection{Inter-annual variability and trends in Arctic storm frequency}

The time series of storm frequency between 1980 and 2017 in winter and summer is shown in Fig. 1. Overall, all of the reanalysis datasets indicate the inter-annual range in Arctic storm frequency is approximately $9-11 \%$ in summer and $11-15 \%$ in winter of the total storm frequency per season. Although, there are seasons of notably high (winter 1988/89 and summer 1989) and low (winter 2009/10 and summer 2011) Arctic storm frequency. These periods coincide with periods of strong low and high phases of the Arctic Oscillation. Figure 1 shows some resemblance to Figure 8 from Simmonds et al. (2008), e.g. the peaks in Arctic storm frequency in summer 1989. Simmonds et al. (2008) showed that from the ERA-40 reanalysis dataset, there is some correlation between Arctic storm frequency and the Arctic Oscillation, one of the leading modes of atmospheric variability in the Arctic. Though, there are some differences between Fig. 1 in this study and Figure 8 from Simmonds et al. (2008), for example the increase in winter 1988/89 across all of the reanalyses.

Previous studies have reported an increasing trend of Arctic storm frequency from 1980, although these studies used previous versions of reanalysis datasets such as the NCEP-NCAR, NCEP-DOE and ERA-40 reanalysis datasets (Zhang et al. 2004; Sorteberg and Walsh 2008; Simmonds et al. 2008). Figure 1 shows that current reanalysis datasets show no significant trend in Arctic storm frequency in winter and summer, which was also found by Zahn et al. (2018). In addition, it is found in Fig. S1 in the supplementary material that there is no significant trend in the frequency of Arctic storms with Arctic genesis and mid-latitude genesis.

Table 1 shows that approximately 50\% of all Arctic storms have mid-latitude genesis in both winter and summer. Figure S1 shows that the variability of storms with Arctic genesis and with mid-latitude genesis both contribute to the variability of all Arctic storms. For example, the decrease in 

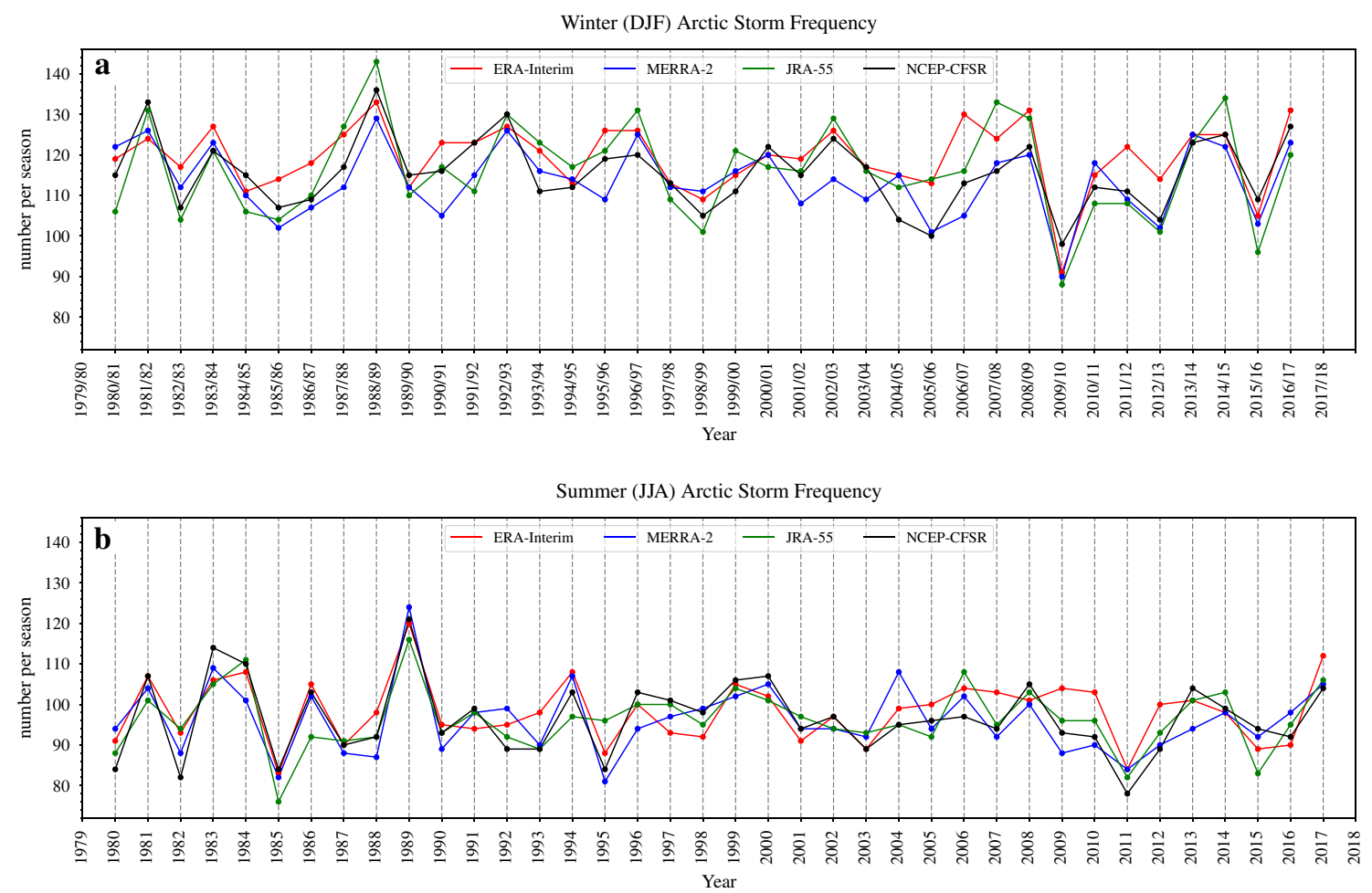

Fig. 1 Time series of the number of Arctic storms that travel north of $65^{\circ} \mathrm{N}$ per season from the ERA-Interim, JRA-55, MERRA-2 and NCEPCFSR reanalysis datasets between a 1980/81-2016/17 in winter (DJF), and, b 1980-2017 in summer (JJA)

Table 2 Pearson correlation coefficients of the inter-annual variability in the frequency per season of all Arctic storms that travel north of $65^{\circ} \mathrm{N}$, Arctic storms with Arctic genesis (north of $65^{\circ} \mathrm{N}$ ) and Arctic storms with mid-latitude genesis (south of $65^{\circ} \mathrm{N}$ ), between the ERA-
Interim, JRA-55, MERRA-2 and NCEP-CFSR reanalysis datasets between 1980/81-2016/17 in winter (DJF) and 1980-2017 in summer (JJA)

\begin{tabular}{|c|c|c|c|c|c|c|}
\hline & \multicolumn{3}{|c|}{ Winter (DJF) } & \multicolumn{3}{|c|}{ Summer (JJA) } \\
\hline & $\begin{array}{l}\text { All Arctic } \\
\text { storms }\end{array}$ & Arctic genesis & $\begin{array}{l}\text { Mid-latitude } \\
\text { genesis }\end{array}$ & $\begin{array}{l}\text { All Arctic } \\
\text { storms }\end{array}$ & Arctic genesis & $\begin{array}{l}\text { Mid- } \\
\text { latitude } \\
\text { genesis }\end{array}$ \\
\hline ERA-Interim, JRA-55 & 0.82 & 0.58 & 0.89 & 0.77 & 0.70 & 0.86 \\
\hline ERA-Interim, MERRA-2 & 0.68 & 0.43 & 0.80 & 0.73 & 0.72 & 0.79 \\
\hline ERA-Interim, NCEP-CFSR & 0.76 & 0.43 & 0.80 & 0.79 & 0.79 & 0.82 \\
\hline JRA-55, MERRA-2 & 0.73 & 0.42 & 0.82 & 0.72 & 0.73 & 0.75 \\
\hline JRA-55, NCEP-CFSR & 0.78 & 0.57 & 0.86 & 0.80 & 0.76 & 0.81 \\
\hline MERRA-2, NCEP-CFSR & 0.62 & 0.62 & 0.79 & 0.83 & 0.71 & 0.73 \\
\hline Average & 0.73 & 0.55 & 0.84 & 0.77 & 0.74 & 0.79 \\
\hline
\end{tabular}

total Arctic storm frequency in winter 2009/10 was mainly due to a low number of storms with mid-latitude genesis, whereas, the increase in total Arctic storm frequency in summer 1989 was due to a high number of storms with Arctic genesis. The variation in Arctic storm frequency with Arctic and mid-latitude genesis is quite similar, with the average standard deviation of storm frequency per season being 6.78 and 7.82 storms in winter, respectively, and 6.85 and 5.53 storms in summer, respectively. This shows that variations in the frequency of Arctic storms with Arctic genesis is as important in determining the frequency of all Arctic storms, as the variations in the frequency of Arctic storms with midlatitude genesis.

The degree of agreement in Arctic storm frequency between the reanalysis datasets can be quantified using the Pearson correlation coefficients of storm frequency 
between 1980 and 2017, and are shown in Table 2. Overall, the correlation coefficient in storm frequency of all Arctic storms between the reanalysis datasets is lower in winter than in summer, with the average correlation between all reanalysis datasets being 0.73 in winter and 0.77 in summer (see Table 2). The lowest correlation coefficients are found when comparing the frequency of Arctic storms with Arctic genesis in winter, with the average correlation between all reanalysis datasets being only 0.55 . In contrast, the average correlation coefficient of winter Arctic storms with midlatitude genesis is much higher (0.84). In summer, the correlation coefficients are relatively similar for storms with Arctic and mid-latitude genesis, 0.74 and 0.79 , respectively. It was noted in Sect. 3.1. that there were larger differences in the climatological Arctic storm frequency in winter than in summer between the reanalysis datasets. Table 2 further shows that there is less agreement in the inter-annual variability of storm frequency in winter than summer, especially for Arctic storms with Arctic genesis.

\section{Arctic storm spatial characteristics}

\subsection{ERA-Interim climatology}

To quantify the differences in the spatial distribution of Arctic storms, the genesis density and track density from the ERA-Interim reanalysis dataset are first calculated, and then the other reanalysis datasets are compared to this frame of reference.

Figure 2 shows the climatology of Arctic storm genesis density and track density in winter and summer between 1980 and 2017 for ERA-Interim. In winter, the Arctic storm track density is highest in the Greenland, Norwegian and Barents Seas (see Fig. 2c). Storms that occur in these regions have genesis in the North Atlantic Ocean, east coast of Greenland and Scandinavia, or have genesis over the Rockies and travel through the Canadian Archipelago and the Labrador Sea. These storms tend to propagate eastward toward the north-west coast of Eurasia. Arctic storm track density is also high over the Canadian Archipelago (see Fig. 2c). Storms that travel into the Canadian Archipelago typically have genesis in the Rockies and around north Greenland (see Fig. 2a). Storms that have genesis around north Greenland tend to travel westward into the Canadian Archipelago, which is not typical of high Northern Hemisphere storms, which tend to propagate eastward. Storms also travel into the Arctic Ocean in winter, which tend to have genesis over the mountainous regions over North Siberia. Previous studies identified few storms that travel into the Canadian Archipelago in winter, which is in contrast to Fig. 2c (Zhang et al.
2004; Tilinina et al. 2014; Crawford and Serreze 2016; Zahn et al. 2018).

In summer, the main Arctic storm track is over the coastline of Eurasia, especially in the Barents Sea and Kara Sea, which extends into the Arctic Ocean north of Eurasia (see Fig. 2d). This is also shown in previous studies (Zhang et al. 2004; Simmonds et al. 2008; Tilinina et al. 2014; Crawford and Serreze 2016; Zahn et al. 2018). Storms along this storm track form along the Arctic Frontal Zone, a region of sharp temperature gradient between the Arctic Ocean and the land, creating a baroclinic environment that leads to storm genesis (Reed and Kunkel 1960; Serreze et al. 2001; Simmonds et al. 2008; Crawford and Serreze 2015; Day and Hodges 2018). It is found in Fig. $2 b$ that storm genesis in this region tends to occur inland rather than over the coastline. This is consistent with Crawford and Serreze (2016) who found that storms in this region have genesis over the interior of coastal Eurasia and that the Arctic Frontal Zone acts to intensify these storms rather than being a region of storm genesis. In addition, storms that have genesis over the east coast of Greenland can travel into both the Eurasian coastline and the Arctic Ocean (see Fig. 2b, d). The storm track in the Canadian Archipelago is less active in summer than in winter, with track density being $15-20$ and 25-30 storms per season, respectively. In winter, storms travel into the Canadian Archipelago from the Rockies and North Greenland. However, in summer, storm genesis around north Greenland is limited, suggesting they are primarily winter phenomena (see Fig. 2a, b).

In Sect. 3.1, it was identified that approximately $50 \%$ of winter and summer Arctic storms have genesis in mid-latitude regions and travel into the Arctic. Figures S2 and S3 in the supplementary material show the storm genesis and track density of Arctic storms with mid-latitude and Arctic genesis. In summer, Arctic storms with mid-latitude genesis can travel deeper into the Arctic Ocean than winter storms (see supplementary material Fig. S2). Storms with Arctic genesis generally stay within the Arctic and rarely travel into mid-latitude regions (see Fig. S3 in supplementary material).

\subsection{Differences in spatial statistics between reanalysis datasets}

Figures 3 and 4 show that ERA-Interim generally has higher Arctic storm track density and genesis density than the other reanalysis datasets. Though, these differences between the reanalysis datasets are generally not statistically significant at a $95 \%$ confidence level. This is likely due to the differences being relatively small compared to the total storm frequency per season (see Figs. 2, 3 and 4). Although, it appears that the differences in Arctic storm track density and genesis density between ERA-Interim and the other reanalysis datasets are higher in winter than in summer. 
In winter, all of the reanalysis datasets show the highest Arctic storm track density to occur over the Greenland, Norwegian and Barents Seas and Canadian Archipelago. In previous studies that used storm tracking algorithms based on MSLP minima or the Laplacian of pressure (geostrophic vorticity), Arctic storm track density was found to be much lower in the Canadian Archipelago than found in this study
Fig. 3 Differences in the climatological storm track density of all Arctic storms that travel north of $65^{\circ} \mathrm{N}$ between a, b ERA-Interim and JRA-55, c, d ERA-Interim and MERRA-2, and e, f ERA-Interim and NCEP-CFSR between 1980/81-2016/17 in winter (DJF) (left panel) and 1980-2017 in summer (JJA) (right panel). Densities have units of number per season per unit area $\left(5^{\circ}\right.$ spherical cap, $\approx 10^{6}$ $\mathrm{km}_{2}$ ). Longitudes are shown every $60 \mathrm{E}$, and latitudes are shown at $80^{\circ} \mathrm{N}, 65^{\circ} \mathrm{N}$ (bold) and $50^{\circ} \mathrm{N}$. Stippling show areas where the differences are statistically significant to a $95 \%$ confidence level

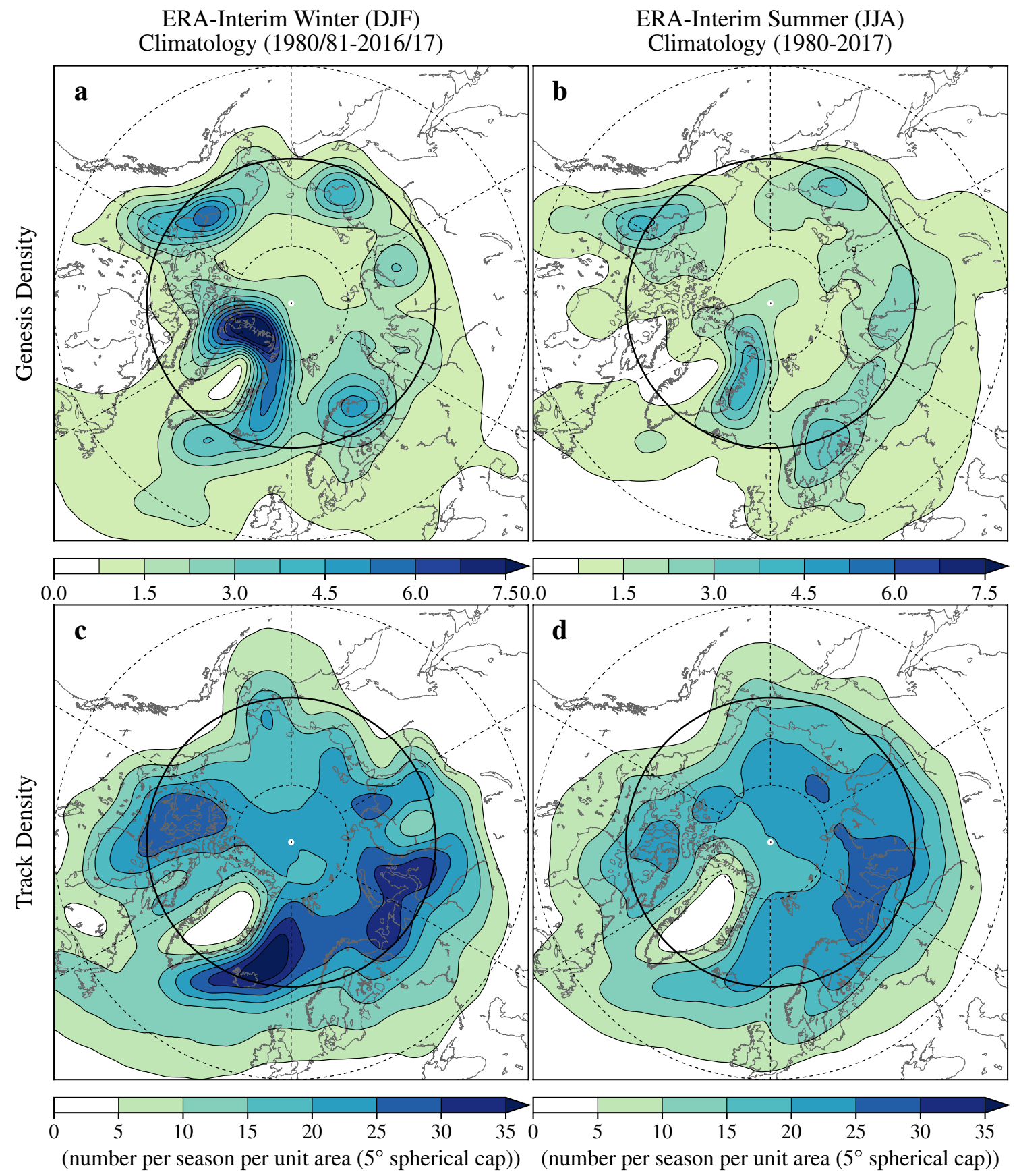

Fig. 2 Climatological $\mathbf{a}, \mathbf{b}$ storm genesis and $\mathbf{c}, \mathbf{d}$ track density of all Arctic storms that travel north of $65^{\circ} \mathrm{N}$ between 1980/81-2016/17 in winter (DJF) (left panel) and 1980-2017 in summer (JJA) (right panel), based on the ERA-Interim reanalysis dataset. Densities have units of number per season per unit area $\left(5^{\circ}\right.$ spherical cap, $\approx 10^{6}$ $\mathrm{km}^{2}$ ). Longitudes are shown every $60^{\circ} \mathrm{E}$, and latitudes are shown at $80^{\circ} \mathrm{N}, 65^{\circ} \mathrm{N}$ (bold) and $50^{\circ} \mathrm{N}$ 
Winter (DJF) Track Density

$(1980 / 81-2016 / 17)$
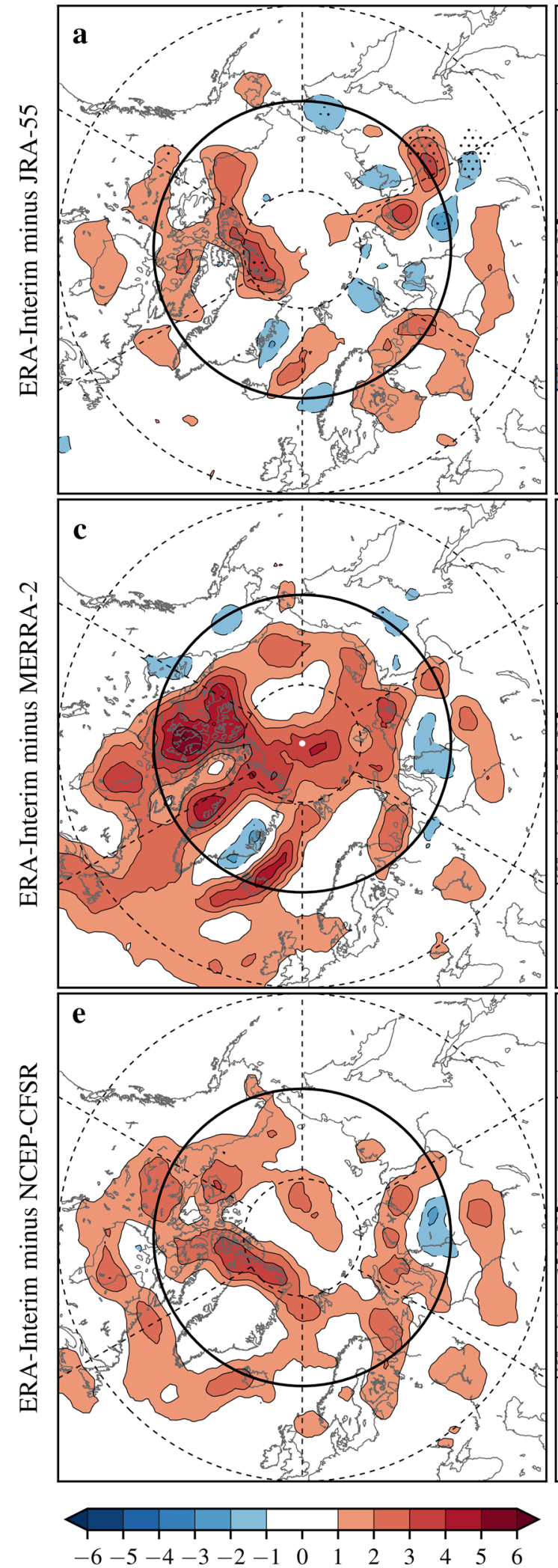

number per season per unit area $\left(5^{\circ}\right.$ spherical cap)
Summer (JJA) Track Density

$(1980-2017)$
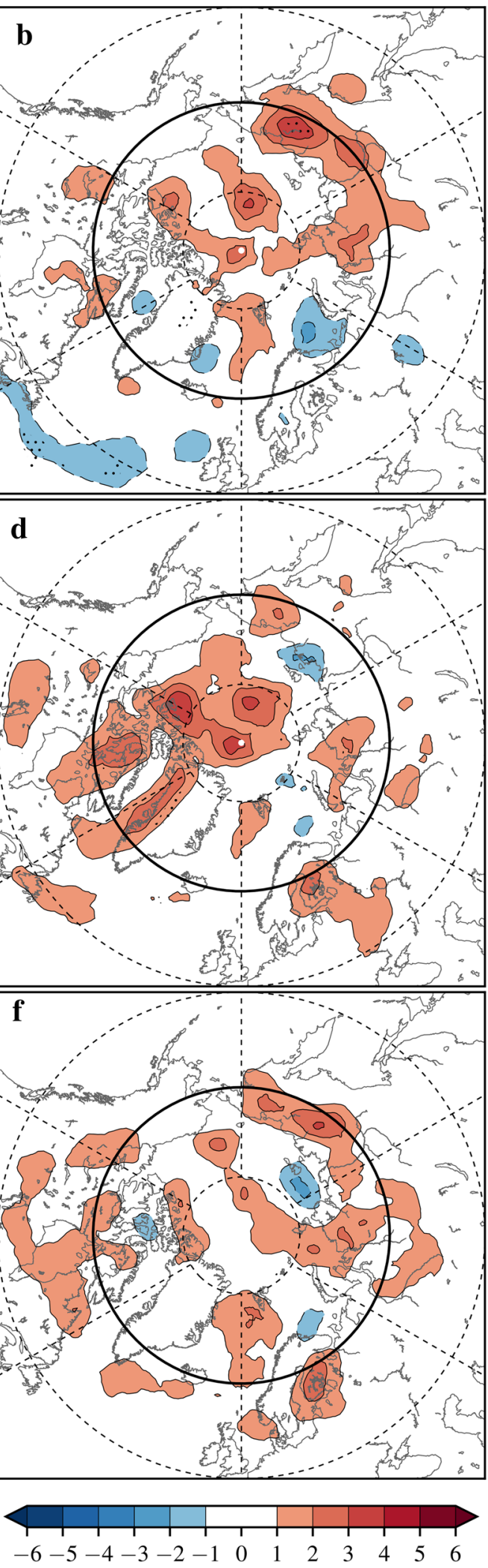

number per season per unit area $\left(5^{\circ}\right.$ spherical cap) 
Winter (DJF) Genesis Density $(1980 / 81-2016 / 17)$
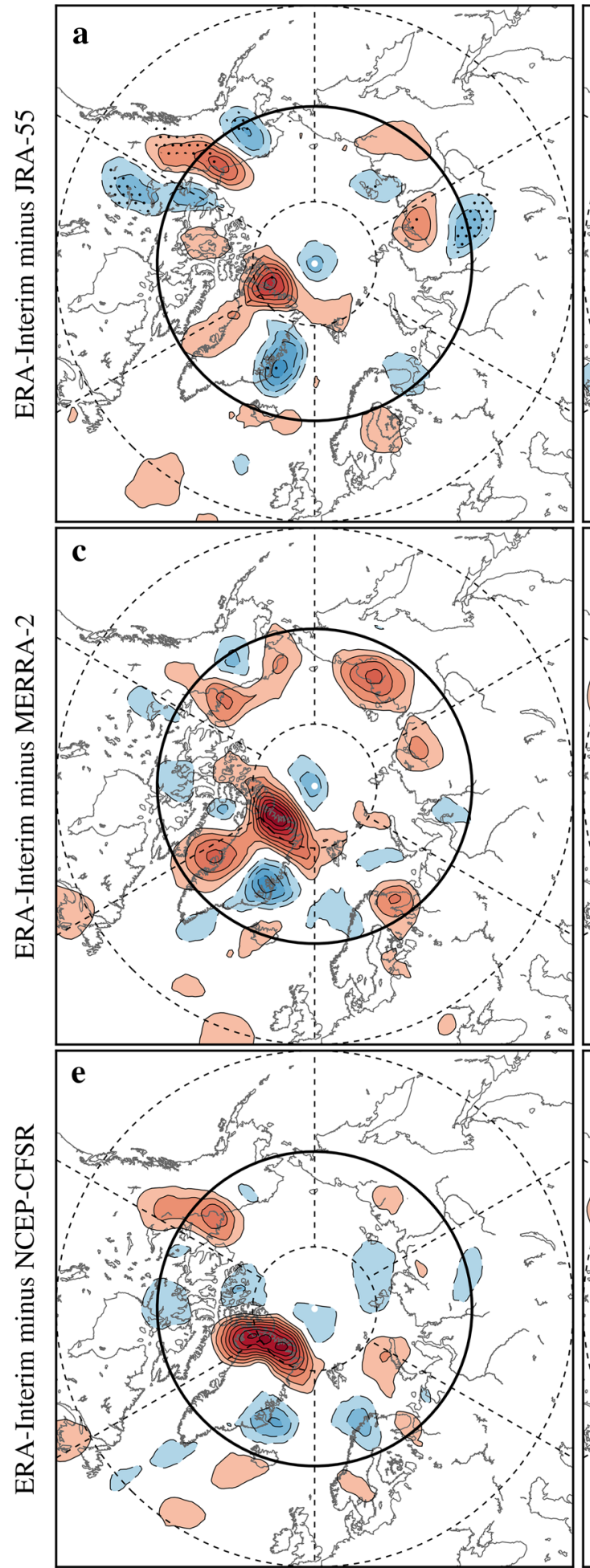

$\begin{array}{lllllll}-3.0-2.4-1.8-1.2-0.60 .0 & 0.6 & 1.2 & 1.8 & 2.4 & 3.0\end{array}$ number per season per unit area $\left(5^{\circ}\right.$ spherical cap)
Summer (JJA) Genesis Density

(1980-2017)
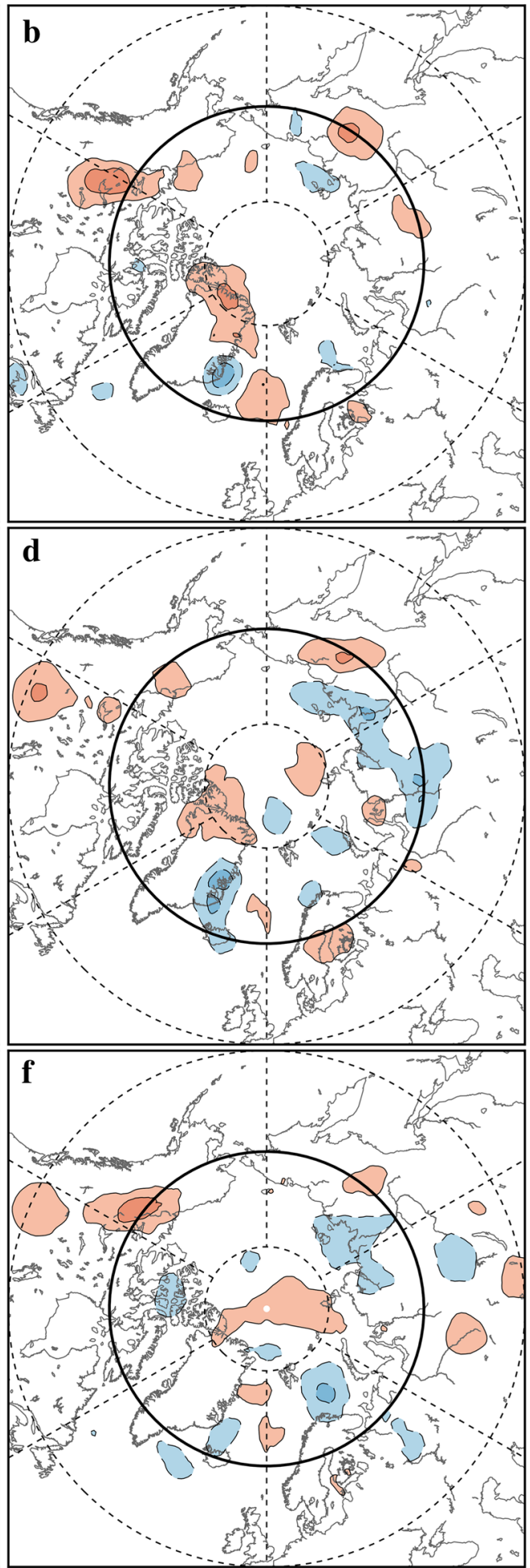

$\begin{array}{lllllll}-3.0-2.4-1.8 & -1.2-0.60 .0 & 0.6 & 1.2 & 1.8 & 2.4 & 3.0\end{array}$ number per season per unit area $\left(5^{\circ}\right.$ spherical cap) 
4Fig. 4 Differences in the climatological storm genesis density of all Arctic storms that travel north of $65^{\circ} \mathrm{N}$ between $\mathbf{a}, \mathbf{b}$ ERA-Interim and JRA-55, c, d ERA-Interim and MERRA-2, and e, f ERA-Interim and NCEP-CFSR between 1980/81-2016/17 in winter (DJF) (left panel) and 1980-2017 in summer (JJA) (right panel). Densities have units of number per season per unit area $\left(5^{\circ}\right.$ spherical cap, $\approx 10^{6}$ $\mathrm{km}^{2}$ ). Longitudes are shown every $60^{\circ} \mathrm{E}$, and latitudes are shown at $80^{\circ} \mathrm{N}, 65^{\circ} \mathrm{N}$ (bold) and $50^{\circ} \mathrm{N}$. Stippling show areas where the differences are statistically significant to a $95 \%$ confidence level

(Zhang et al. 2004; Simmonds et al. 2008; Tilinina et al. 2014; Crawford and Serreze 2016; Zahn et al. 2018). The differences in Arctic storm track density between ERA-Interim and the other reanalysis datasets are highest in the Canadian Archipelago (see Fig. 3a, c, e). In this region, ERA-Interim has higher track density than the other reanalysis datasets and the largest differences are between ERA-Interim and MERRA-2, with the track density in MERRA-2 being 4-5 storms lower per season per unit area than ERA-Interim. The largest differences in storm genesis density occur over high terrain over north Greenland and over the Rockies (see Fig. 4a, c, e); these storms generally travel into the Canadian Archipelago (see Fig. 4). In addition, ERA-Interim has higher Arctic storm track density over the Greenland, Norwegian and Barents Seas than MERRA-2 and NCEP-CFSR (see Fig. 3c, e). Storms that occur in this region tend to propagate toward the north-west coast of Eurasia, where there are also large differences in storm track density between ERA-Interim and MERRA-2, and, ERA-Interim and NCEPCFSR. MERRA-2 also shows lower storm track density over the Kara and Laptev Seas and lower storm genesis density over central north Siberia.

In summer, the differences in Arctic storm track density and genesis density are smaller than in winter, with ERAInterim generally having higher track density than the other reanalysis datasets. In winter and summer, the largest differences in storm track density have a magnitude of $\geq 5$ and 3-4 storms per season per unit area, respectively. The differences in the storm track density, over the main summer storm track, over of the coastline of Eurasia is small, less than two storms per season per unit area (see Fig. 3b, d, f). This indicates that all of the reanalysis datasets show a consistent behaviour in that the Arctic storm activity shifts from predominately over the Canadian Archipelago and the Greenland, Norwegian and Barents Seas in winter, to over the coast of the Eurasian continent in summer (see Fig. 3b, d, f). In summer, JRA-55 and NCEP-CFSR show lower track density over Siberia than ERA-Interim (see Fig. 3b), whereas, MERRA-2 shows lower track density over the Arctic Ocean (see Fig. 3d). It was shown in ERA-Interim that the Arctic storm genesis occurs inland of the Arctic Frontal Zone, which is consistent with the conclusions of Crawford and Serreze (2016). The differences in genesis density are small over inland Eurasia (see Fig. 4b, d, f), thus, in all of the reanalysis datasets, Arctic storm genesis is shown to occur inland of the Arctic Frontal Zone.

\section{Storm intensity}

\subsection{Climatological Arctic storm intensity}

Figure 5 shows that Arctic storms are more intense in winter than in summer in terms of maximum $925 \mathrm{hPa}$ wind speed and minimum MSLP (see Fig. 5). This is consistent with previous studies (Zhang et al. 2004; Sorteberg and Walsh 2008; Simmonds et al. 2008). The minimum MSLP distributions of Arctic storms are more consistent across the reanalysis datasets than the maximum $925 \mathrm{hPa}$ wind speed (see Fig. 5). There is more similarity in the minimum MSLP distributions of Arctic storms between the reanalysis datasets in summer than in winter, with the spread between the reanalysis datasets in the mean MSLP minimum being $0.8 \mathrm{hPa}$ and $2.0 \mathrm{hPa}$ in summer and winter, respectively. Though, there is good agreement in the minimum central MSLP of the most intense storms between the reanalysis datasets in both seasons. MERRA-2 shows fewer weak storms in winter, whereas, ERA-Interim, JRA55 and NCEP-CFSR have similar distributions of weak storms. Zahn et al. (2018) also compared the minimum MSLP of Arctic storms between the datasets shown in Fig. 5, and also found that the distributions of the more intense storms are more in agreement between the datasets.

The maximum $925 \mathrm{hPa}$ wind speed distributions of Arctic storms between ERA-Interim, JRA-55, MERRA-2 and NCEP-CFSR has not been considered in previous studies. In summer, ERA-Interim and JRA-55 show Arctic storms to have lower maximum $925 \mathrm{hPa}$ winds speeds (with means of 20.9 and $20.4 \mathrm{~m} / \mathrm{s}$, respectively) than MERRA-2 and NCEPCFSR (with means of 22.8 and $22.8 \mathrm{~m} / \mathrm{s}$, respectively) (see Fig. 5a, b). Wind speeds at $925 \mathrm{hPa}$ are produced at a lower horizontal resolution in ERA-Interim $\left(0.75^{\circ} \times 0.75^{\circ}\right)$ and JRA-55 $\left(1.25^{\circ} \times 1.25^{\circ}\right)$ than MERRA-2 $\left(0.625^{\circ} \times 0.5^{\circ}\right)$ and NCEP-CFSR $\left(0.5^{\circ} \times 0.5^{\circ}\right)$, and lower horizontal resolution tends to smooth the wind field and result in lower wind speeds. In winter, MERRA-2 and NCEP-CFSR indicate a more intense distribution of maximum $925 \mathrm{hPa}$ winds speeds, whereas, ERA-Interim and JRA-55 are lower. There is less consistency between MERRA-2 and NCEP-CFSR in winter than in summer, despite their similar horizontal resolution, with the means of the maximum $925 \mathrm{hPa}$ wind speed distributions in winter being 27.6 and $26.9 \mathrm{~m} / \mathrm{s}$, respectively.

The inter-annual variability of the maximum $925 \mathrm{hPa}$ wind speed and minimum MSLP of the ten most intense Arctic storms per season in winter and summer are shown in Fig. S4 in the supplementary material. There is no significant trend in Arctic storm intensity between 1980 and 2017 in terms of 

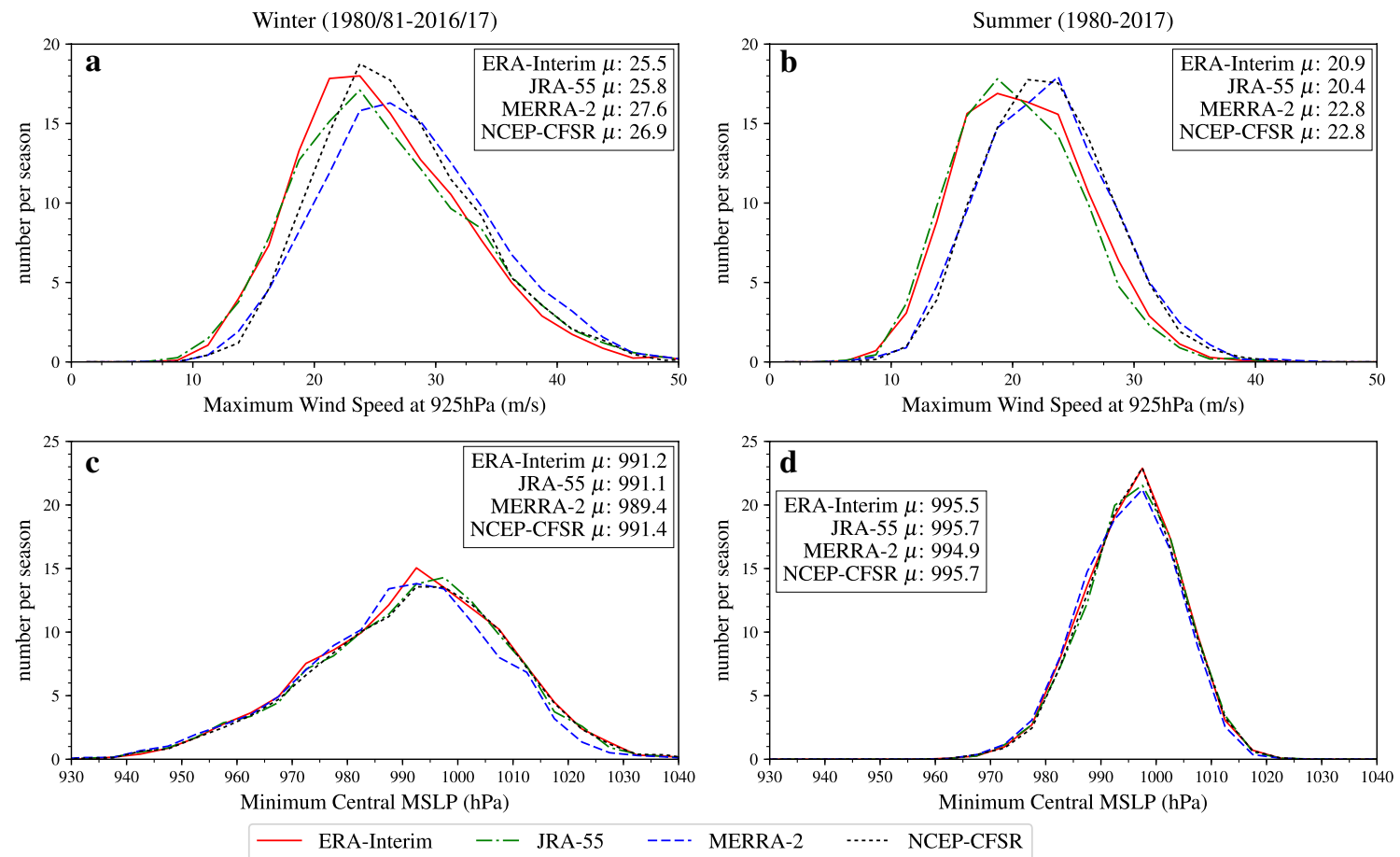

Fig. 5 Frequency distributions of the maximum intensity of $\mathbf{a}, \mathbf{b} 925$ $\mathrm{hPa}$ wind speed, and $\mathbf{c}, \mathbf{d}$ minimum central mean sea level pressure (MSLP) of all winter (DJF) Arctic storms between 1980/81-2016/17 (left panel) and summer (JJA) Arctic storms between 1980-2017

maximum $925 \mathrm{hPa}$ wind speed and minimum MSLP in both winter and summer. The inter-annual variability of the intensity of extreme Arctic storms is higher in winter than summer. The standard deviation in the mean winter and summer maximum wind speed and minimum MSLP of the extreme Arctic storms is shown to be less than $2.27 \mathrm{~m} / \mathrm{s}$ and $1.31 \mathrm{~m} / \mathrm{s}$, and 6.22 $\mathrm{hPa}$ and $2.65 \mathrm{hPa}$, respectively. There is higher consistency between the reanalysis datasets in the minimum central MSLP of the most intense Arctic storms, than the maximum $925 \mathrm{hPa}$ wind speeds, which is also shown in Fig. 5. It is shown that the

(right panel) from ERA-Interim, JRA-55, MERRA-2 and NCEPCFSR. Bin widths are $2.5 \mathrm{~m} / \mathrm{s}$ for $925 \mathrm{hPa}$ wind speed and $5 \mathrm{hPa}$ for MSLP and the mean $(\mu)$ of the distribution is given for each dataset. Intensity is taken when the storm is north of $65^{\circ} \mathrm{N}$

maximum intensity of the most intense storms, in terms of the maximum $925 \mathrm{hPa}$ wind speed per year, is different between the reanalysis datasets in both winter and summer.

\section{Arctic storm track matching}

The reanalysis datasets attempt to capture the same atmospheric conditions between 1980 and 2017, thus, they should capture the same storms. To test this, a storm matching

Table 3 Percentage of Arctic storms (storms that travel north of $65^{\circ} \mathrm{N}$ ) and mid-latitude storms (storms that have genesis between $35^{\circ} \mathrm{N}$ and $65^{\circ} \mathrm{N}$ ) that match between the ERAInterim, JRA-55, MERRA-2 and NCEP-CFSR reanalysis datasets in winter (DJF) between 1980/81-2016/17 and in summer (JJA) between 1980-2017

\begin{tabular}{|c|c|c|c|c|}
\hline & \multicolumn{2}{|l|}{ Winter (DJF) } & \multicolumn{2}{|l|}{ Summer (JJA) } \\
\hline & $\begin{array}{l}\text { Arctic storms } \\
(\%)\end{array}$ & $\begin{array}{l}\text { Mid-latitude } \\
\text { storms }(\%)\end{array}$ & $\begin{array}{l}\text { Arctic storms } \\
(\%)\end{array}$ & $\begin{array}{l}\text { Mid-lati- } \\
\text { tude storms } \\
(\%)\end{array}$ \\
\hline ERA-Interim, JRA-55 & 82.4 & 85.2 & 83.7 & 84.7 \\
\hline ERA-Interim, MERRA-2 & 79.1 & 84.2 & 81.9 & 83.6 \\
\hline ERA-Interim, NCEP-CFSR & 81.5 & 84.8 & 83.1 & 84.1 \\
\hline JRA-55, MERRA-2 & 78.6 & 83.7 & 82.2 & 82.9 \\
\hline JRA-55, NCEP-CFSR & 82.0 & 84.3 & 82.9 & 83.0 \\
\hline MERRA-2, NCEP-CFSR & 81.4 & 83.6 & 83.1 & 83.3 \\
\hline Average & 80.8 & 84.3 & 82.8 & 83.6 \\
\hline
\end{tabular}

Matching criteria are that the storm tracks must have a mean separation distance less than $4^{\circ}$ (geodesic), and overlap in time by at least $50 \%$ of the points in their life cycle 

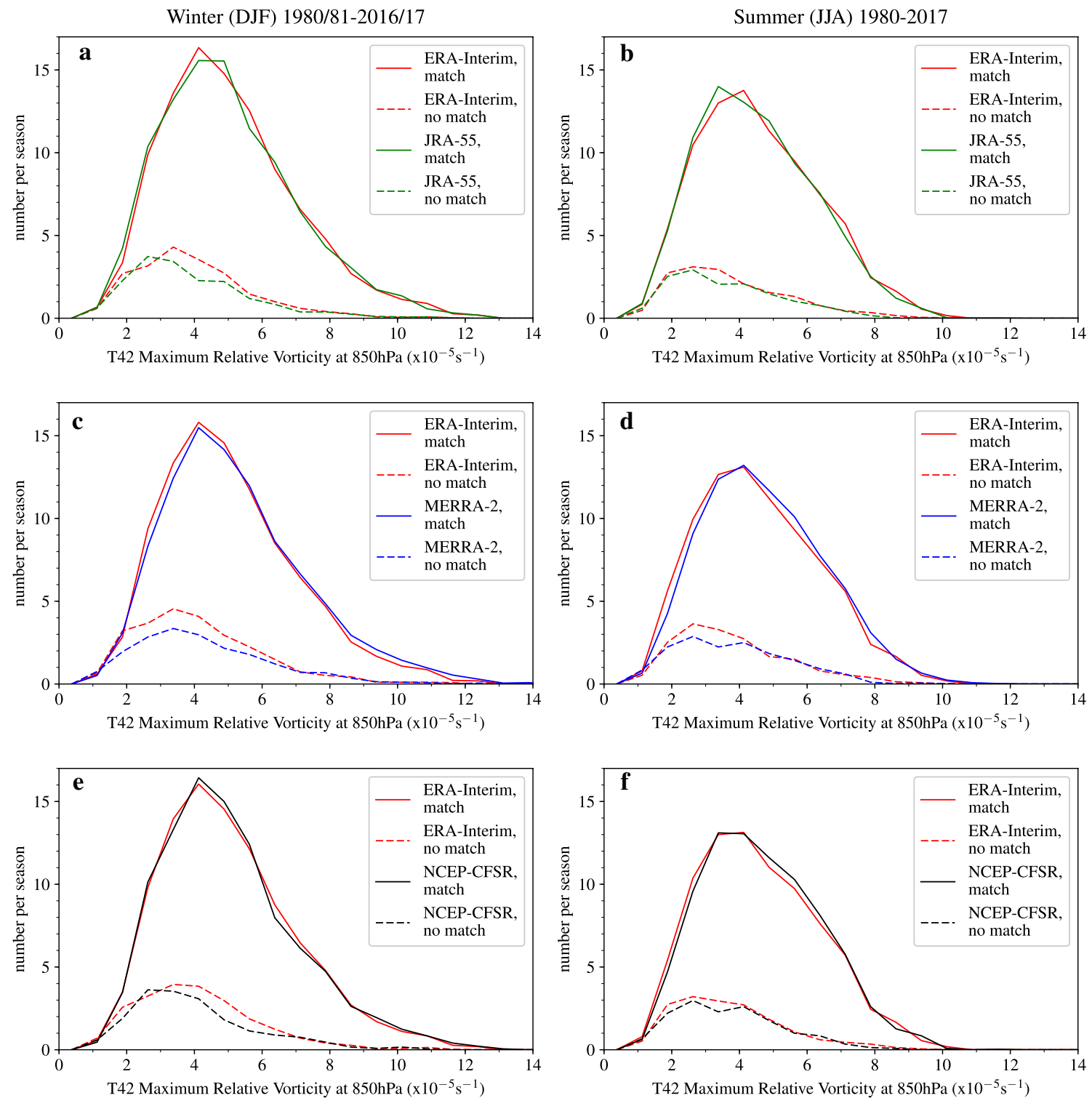

Fig. 6 Maximum $850 \mathrm{hPa}$ T42 relative vorticity distributions of Arctic storms from ERA-Interim that match with a, b JRA-55, c, d MERRA-2, and e, f NCEP-CFSR, between the period of 1980/812016/17 in winter (DJF) (left panel) and 1980-2017 in summer (JJA)

(right panel). Storm tracks match if they are separated by a distance less than $4^{\circ}$ (geodesic) and $50 \%$ of the points in the track occur at the same time. Bin widths are $0.75 \times 10^{-5} \mathrm{~s}^{-1}$. Intensity is taken when the storm is north of $65^{\circ} \mathrm{N}$.

algorithm has been used to compare the Arctic storms identified in each reanalysis dataset (Hodges et al. 2011). A comparison is also made between Arctic and mid-latitude storms, to contrast the agreement between the reanalysis datasets in Arctic and mid-latitude regions.

Table 3 provides a summary of the percentage of storms that match in winter and summer between the reanalysis datasets. Overall, the percentage of Arctic storms that match between the reanalysis datasets is slightly higher in summer than in winter. The average percentage of storms between the reanalysis datasets that match in summer is $82.8 \%$ and in winter is $80.8 \%$. The difference of $2 \%$ equates to approximately 80 storms between 1980 and 2017. The highest percentage of matches of Arctic storms between the reanalysis datasets in winter and in summer is between ERA-Interim and JRA-55, whereas, the lowest percentage of Arctic storms that match in winter is between JRA-55 and MERRA-2 and in summer is between ERA-Interim and MERRA-2. The percentage of mid-latitude storms that match between the reanalysis datasets is slightly higher than that of Arctic storms in both seasons. This shows that there is more agreement in storms captured in the reanalysis datasets in mid-latitude regions than in Arctic regions, especially in winter. 
Figure 6 shows the maximum $850 \mathrm{hPa}$ T42 relative vorticity of Arctic storms from JRA-55, MERRA-2 and NCEPCFSR that match and do not match with storms from ERAInterim. Generally, the more intense Arctic storms match well between the reanalysis datasets, and it is the weaker Arctic storms that do not match between the reanalysis datasets. This is found to occur between ERA-Interim and all of the other reanalysis datasets.

To test the sensitivity, the analysis was also performed with stricter criteria where the storm tracks must have a mean separation distance less than $2^{\circ}$ (geodesic), and overlap in time by at least $75 \%$ of the points in their life cycle (see Fig. S5 and Table S1 in the supplementary material). Using this stricter criteria, it is also found that generally the more intense Arctic storms still match well between the reanalysis datasets, and it is the weaker Arctic storms that don't match between the reanalysis datasets. Winter is found to have a lower percentage of Arctic storms that match than summer, $64.3 \%$ and $68.2 \%$, respectively. In winter, the percentage of matching mid-latitude storms between the reanalysis datasets is also higher than that of Arctic storms when using these stricter criteria, $69.2 \%$ and $64.2 \%$, respectively. Though, the percentage of matching of summer storms is slightly higher in Arctic regions than mid-latitude regions, $68.2 \%$ and $67.7 \%$, respectively. Zahn et al. (2018) showed that approximately $60 \%$ of Arctic storms match between the reanalysis datasets using similar matching criteria to that used in this study, which are similar to results found in this study. Thus, there is more certainty between the reanalysis datasets in the location and time of the most intense Arctic storms.

\section{Mean sea level pressure field based versus relative vorticity field based storm tracking algorithm}

Results from this study have some differences from previous studies. In Sect. 3.1, it was shown that there is higher storm frequency in winter than summer using storm tracking based on $850 \mathrm{hPa}$ relative vorticity, which differs from the results of Serreze (1995), Serreze et al. (2001), Tilinina et al. (2014) and Zahn et al. (2018). In Sect. 4.1, the Canadian Archipelago was found to be an area of high storm track density in winter and summer; an area that has not been previously shown to have high storm activity (Zhang et al. 2004; Tilinina et al. 2014; Crawford and Serreze 2016; Zahn et al. 2018). In this study, the storm tracking algorithm is based on the $850 \mathrm{hPa}$ relative vorticity field, whereas, most previous studies use a storm tracking algorithm based on minima in the MSLP field.

Table 4 shows the number of storms per season in winter and summer is different when the storm tracking is based on
Table 4 Frequency of all Arctic storms that travel north of $65^{\circ} \mathrm{N}$ per season between 1980/81-2016/17 in winter (DJF) and 1980-2017 in summer (JJA) identified by the storm tracking algorithm developed by Hodges $(1994,1995,1999)$ based on the $850 \mathrm{hPa}$ relative vorticity field (VOR850) and on the mean sea level pressure field (MSLP)

\begin{tabular}{lll}
\hline & $\begin{array}{l}\text { Winter (DJF) } \\
(1980 / 81-2016 / 17) \\
\text { season) }\end{array}$ & $\begin{array}{l}\text { Summer (JJA) } \\
(1980-2017)(\text { per } \\
\text { season) }\end{array}$ \\
\hline $\begin{array}{l}\text { ERA-Interim VOR850 } \\
\text { T42 }\end{array}$ & 119.4 & 98.3 \\
$\begin{array}{l}\text { ERA-Interim MSLP } \\
\text { T63 }\end{array}$ & 64.4 & 65.6 \\
\hline
\end{tabular}

the $850 \mathrm{hPa}$ relative vorticity field and on the MSLP field. When using the MSLP field, Arctic storm frequency in summer and winter is similar, which is in agreement with Serreze (1995), Serreze et al. (2001), Tilinina et al. (2014) and Zahn et al. (2018). In contrast, Arctic storm frequency is higher in winter than summer when basing the storm tracking algorithm on $850 \mathrm{hPa}$ relative vorticity. Although Crawford and Serreze (2016) showed that 31 more storms (approximately 1 more storm per season) had occurred between 1979 and 2014 in winter (DJF) than in summer (JJA) when using a storm tracking algorithm based on MSLP, the differences between using $850 \mathrm{hPa}$ relative vorticity and MSLP, shown in Table 4 for each season, are substantially higher. Table 1 shows that for ERA-Interim, 21 more storms per season occur in winter (DJF) than in summer (JJA) when using storm tracking based on $850 \mathrm{hPa}$ relative vorticity. Relative vorticity is able to represent smaller spatial scales than MSLP, thus storm tracking algorithms based on the vorticity field are able to identify more smaller scale storms than those based on MSLP (Hoskins and Hodges 2002; Neu et al. 2013), even if relative vorticity is at lower resolution than the MSLP (T42 rather than T63) (Jung et al. 2012).

Figure 7a, b show the spatial differences in Arctic storm track density in winter and summer between using $850 \mathrm{hPa}$ relative vorticity and MSLP as the identification variable. The differences are of higher magnitude in winter than in summer, with the largest differences occurring in the Canadian Archipelago in winter and in summer, with magnitudes of 22+ and 14-16 storms per season per unit area, respectively. Additional storms are also identified using relative vorticity in the Greenland Sea, the Arctic Ocean and north of coastal Siberia in summer and winter. In winter, additional storms are also found over Scandinavia, inland Siberia and the Bering Strait when using relative vorticity. Although the MSLP and $850 \mathrm{hPa}$ relative vorticity fields have been filtered to a spatial resolution of T63 and T42, respectively, this should in fact lead to the MSLP storm tracking to identify more storms (Blender and Schubert 2000). In Sect. 4.1 it was found that the track density of Arctic storms was significantly higher in the Canadian Archipelago using relative 


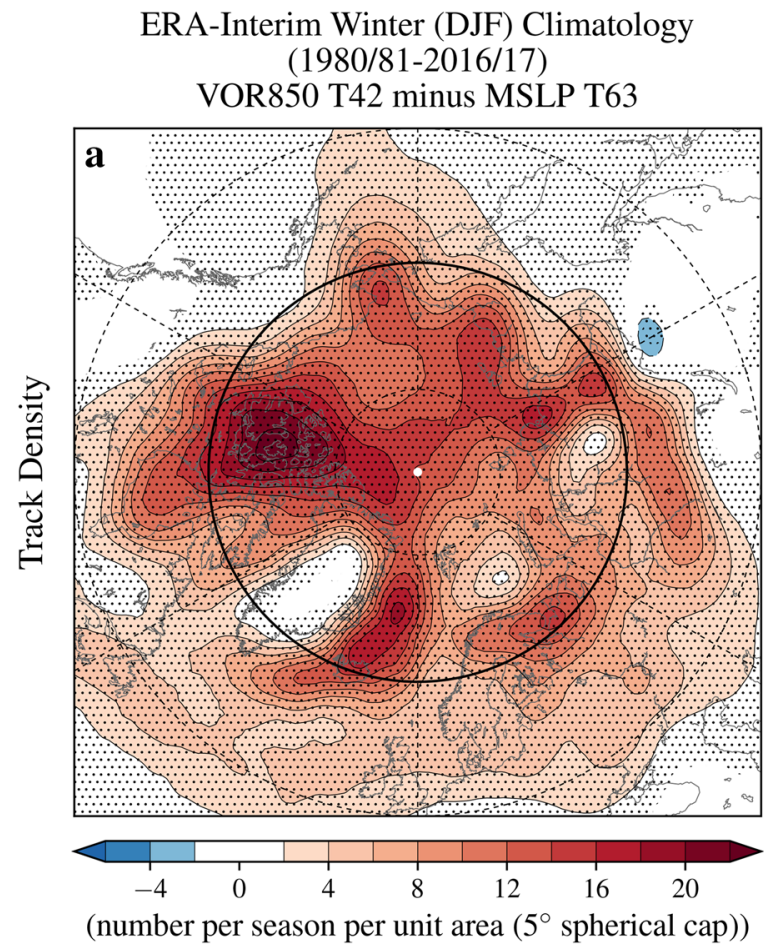

Fig. 7 Differences in the climatological storm track density of all Arctic storms that travel north of $65^{\circ} \mathrm{N}$ identified by a storm tracking algorithm based on the $850 \mathrm{hPa}$ relative vorticity field (VOR850) and the mean sea level pressure field (MSLP) between a 1980/81-

vorticity than shown previously by Zhang et al. (2004), Tilinina et al. (2014), Crawford and Serreze (2016) and Zahn et al. (2018) which all used MSLP tracking. Differences between this study and previous studies could be due to using storm tracking based on $850 \mathrm{hPa}$ relative vorticity or MSLP (Neu et al. 2013). Although, the differences could also arise from a number of other reasons. One reason may be that previous studies have used a higher resolution storm tracking variable, whereas, in this study, $850 \mathrm{hPa}$ relative vorticity is smoothed to T42 spectral resolution (Blender and Schubert 2000). Previous studies may also use different filtering thresholds of the intensity, lifespan and track length of the storms, and, may also filter out storms over high orography (Rudeva et al. 2014; Pinto et al. 2005). However, Table 4 and Figure 7 show the differences in Arctic storm frequency and track density between using storm tracking based on 850 $\mathrm{hPa}$ relative vorticity and MSLP using the same method.

It is notable that the differences in Arctic storm frequency when using $850 \mathrm{hPa}$ relative vorticity and MSLP as the storm tracking variable are much higher than the differences in Arctic storm frequency between the reanalysis datasets (see Tables 1 and 4). The highest differences in Arctic storm track density between using $850 \mathrm{hPa}$ relative vorticity or MSLP for the storm tracking, shown in Figure 7, exceed 21 storms per season. In comparison, the highest differences

\section{ERA-Interim Summer (JJA) Climatology (1980-2017) VOR850 T42 minus MSLP T63}

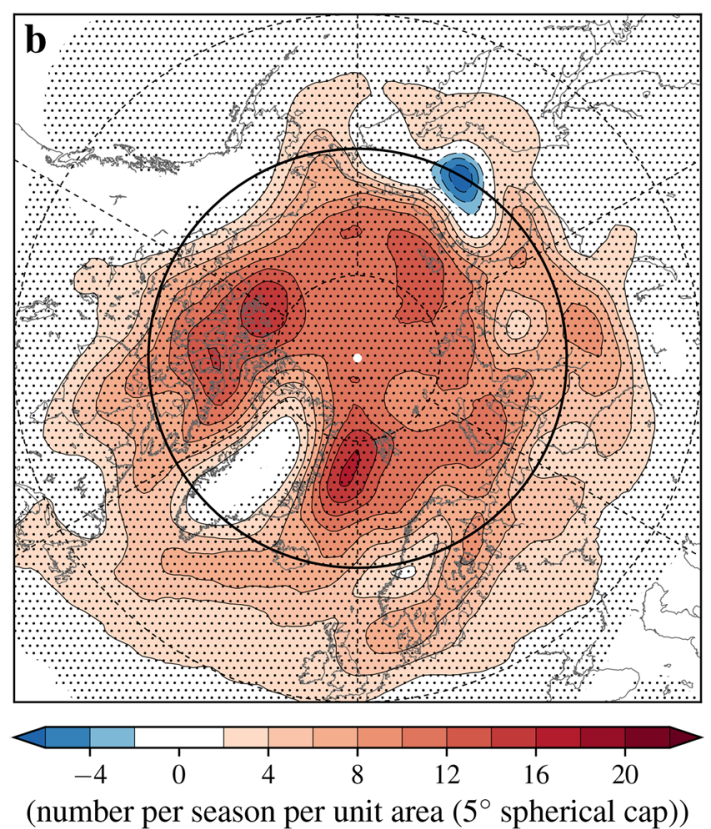

2016/17 in winter (DJF) (left panel) and b 1980-2017 in summer (JJA), based on the ERA-Interim reanalysis dataset. Stippling show areas where the differences are statistically significant to a $99 \%$ confidence level

in Arctic storm track density between the reanalysis datasets is between 5-6 storms per season (see Fig. 3). Furthermore, there are also more statistically significant differences between Arctic storm track density shown in Fig. 7 than in Fig. 3, even at a higher confidence level of $99 \%$ rather than $95 \%$.

\section{Summary and conclusions}

The spatial distribution, frequency and intensity of Arctic storms has been compared between the ERA-Interim, JRA55, MERRA-2 and NCEP-CFSR reanalysis datasets. Arctic storms were identified using a tracking scheme based on the $850 \mathrm{hPa}$ relative vorticity field, with the emphasis on mobile synoptic-scale storms that travel north of $65^{\circ} \mathrm{N}$ in winter (DJF) and summer (JJA). The objectives are to quantify the climatological and inter-annual characteristics of Arctic storms and how different these characteristics are between multiple reanalysis datasets, and also when using two different storm tracking identification variables, $850 \mathrm{hPa}$ relative vorticity and mean sea level pressure (MSLP). 
- There are no significant trends in Arctic storm characteristics between 1980 and 2017 in winter (DJF) or summer (JJA).

Despite the Arctic climate changing dramatically over the past few decades, no significant trend was found in the frequency of Arctic storms in winter and summer between 1980 and 2017 in all of the reanalysis dataset. This was also found by Zahn et al. (2018). In addition, Arctic storms have been separated into storms that have Arctic genesis and midlatitude genesis in this study. It was found that there were no significant trends in the frequency of Arctic storms with Arctic genesis or mid-latitude genesis in winter and summer. Similarly, no significant trends were found in the intensity of the ten most intense storms per season between 1980 and 2017.

Given that the observations assimilated in the Arctic are sparser than in mid-latitude regions, it may be expected that the differences in the Arctic storm characteristics between the reanalysis datasets may be larger than in mid-latitudes. However, this study has identified some robust characteristics of Arctic storms that are consistent between the four reanalysis datasets. For example, in winter, the areas with the highest Arctic storm track density occur in the Greenland, Norwegian and Barents Seas and the Canadian Archipelago, whereas, in summer, Arctic storm track density is highest over and north of continental Eurasia. In addition, the four reanalysis datasets show that approximately $50 \%$ of all Arctic storms have Arctic genesis (north of $65^{\circ} \mathrm{N}$ ) and mid-latitude genesis (south of $65^{\circ} \mathrm{N}$ ). Arctic storms were also found to become more intense in winter than in summer, in terms of their minimum MSLP and maximum $925 \mathrm{hPa}$ wind speed. All four of the reanalysis datasets show that the inter-annual variability in Arctic storm frequency is small, approximately $15 \%$ of the total storm number (about 15-20 storms per season). Although there are similarities in Arctic storm characteristics between the reanalysis datasets, there are also differences.

- The differences in Arctic storm characteristics between the reanalysis datasets are higher in winter (DJF) than in summer (JJA).

Greater differences were found when comparing the Arctic storm track density and genesis density of JRA-55, MERRA-2 and NCEP-CFSR with ERA-Interim in winter than in summer. The greatest differences in track density were found to occur over the Canadian Archipelago in winter, where track density differed by as much as 5-6 storms per season per unit area ( $5^{\circ}$ spherical cap). In comparison, the differences in summer Arctic storm track density did not exceed 3-4 storms per season per unit area. When comparing the inter-annual variability in the frequency of Arctic storms between the reanalysis datasets, the average Pearsons correlation coefficient for storms with Arctic genesis between the reanalysis datasets across the time series was found to be 0.55 in winter, but 0.74 in summer. The differences between the four reanalysis datasets in Arctic storm frequency were also found to be higher in winter than in summer, differences of 5.7 and 2.1 storms per season, respectively. The percentage of Arctic storms that match between the reanalysis datasets was also found to be higher in summer than in winter across all of the reanalysis datasets.

Arctic winter poses significant challenges for the creation of global atmospheric reanalyses. From an observational perspective there is a low density of conventional observations, and difficulties in identifying cloud and estimating emissivity over snow and ice limit the current use of infrared and microwave satellite data in the troposphere (Jung et al. 2016). From a physical perspective there is a frequent occurrence of conditions that are hard to represent in numerical models, like stable boundary layers and mixed phase clouds (Sandu et al. 2013; Pithan et al. 2016). Difficulties may also arise from large differences between the background state of the numerical models and the observations, which may lead to the data assimilation scheme to reject some observations (Lawrence et al. 2019). It is plausible that these factors may contribute to greater differences in Arctic storm characteristics between the reanalysis datasets found in winter than in summer.

- Approximately half of all Arctic storms have Arctic genesis (north of $65^{\circ} \mathrm{N}$ ) and half of all Arctic storms have mid-latitude genesis (south of $65^{\circ} \mathrm{N}$ ) in winter (DJF) and summer (JJA).

It was found that an average of $54.4 \%$ and $47.4 \%$ of all Arctic storms across the reanalysis datasets have genesis in the Arctic (north of $65^{\circ} \mathrm{N}$ ) in winter and summer, respectively. This shows that storms are a significant mechanism for transporting air from low to high latitudes. The differences between the reanalysis datasets are generally higher when comparing Arctic storms with Arctic genesis than comparing Arctic storms with mid-latitude genesis. This is particularly true in winter. When comparing the inter-annual variability in the frequency of Arctic winter storms between the reanalysis datasets between 1980/81 and 2016/17, the average Pearsons correlation coefficient for storms with Arctic genesis across the reanalysis datasets was found to be 0.55 , compared to an average Pearsons correlation coefficient of 0.84 for Arctic storms with mid-latitude genesis. In comparison, the average Pearsons correlation coefficient of the frequency of summer Arctic storms with Arctic and mid-latitude genesis is 0.74 and 0.79, which is higher for Arctic storms with mid-latitude genesis. In addition, the average percentage of storms that 
match between the reanalysis datasets was found to be higher for mid-latitude storms than Arctic storms, 80.8\% and 84.3\% in winter, respectively, and $82.8 \%$ and $83.6 \%$ in summer, respectively. This highlights the additional challenges in producing atmospheric reanalyses in the Arctic compared to mid-latitude regions, especially in winter.

- The representation of Arctic storm characteristics identified in reanalysis datasets are dependent on the storm tracking variable.

Basic properties of the Arctic storm climatology, such as whether the total number of storms in the summer is larger or smaller than in winter, are dependent on whether one uses relative vorticity or MSLP as the storm tracking variable. Previous studies (such as Serreze (1995), Serreze et al. (2001), Tilinina et al. (2014) and Zahn et al. (2018)) show that Arctic storm frequency is higher in summer than in winter. These studies identified Arctic storms in reanalysis datasets using a storm tracking algorithm based on the MSLP field, whereas, in this study, Arctic storm characteristics were compared between storms identified in the ERAInterim dataset based on MSLP and on $850 \mathrm{hPa}$ relative vorticity.

In this study, the storm tracking using the MSLP field was found to identify fewer storms than the $850 \mathrm{hPa}$ relative vorticity storm tracking. Different seasonal patterns of Arctic storm frequency are obtained using the two different tracking variables, with storm frequency being similar in winter and summer using MSLP (64.4 and 65.6 storms per season, respectively), whereas, when using $850 \mathrm{hPa}$ relative vorticity the frequency of Arctic storms is higher in winter than in summer (119.4 and 98.3 storms per season, respectively). The differences in Arctic storm track density between the two identification variables was found to be higher in winter than in summer, with the highest differences occurring over the Canadian Archipelago and the North Atlantic Ocean. The differences between the $850 \mathrm{hPa}$ relative vorticity and MSLP storm tracking were substantially larger than the differences found between the reanalysis datasets. In winter, Arctic storm frequency differed by 55 storms per season between the $850 \mathrm{hPa}$ relative vorticity and MSLP storm tracking, whereas, between the reanalysis datasets, storm frequency in winter only differed by as much as 5.7 storms per season.

Relative vorticity in general focuses on smaller spatial scales than MSLP. Thus, storm tracking algorithms based on the relative vorticity field are able identify more smaller scale storms than those based on MSLP (Hoskins and Hodges 2002; Neu et al. 2013). It is plausible that these smaller scale storms tend to occur more in winter than in summer, as larger differences in Arctic storm characteristics has been found in winter than in summer between storm tracking based on relative vorticity and MSLP. In this study, it was found that there are larger differences in Arctic storm frequency per season and track density between identifying storms using the $850 \mathrm{hPa}$ relative vorticity compared to using MSLP, than differences between the different reanalysis datasets. This shows that the decision to use $850 \mathrm{hPa}$ relative vorticity or MSLP for storm tracking can be more important than the choice of reanalysis dataset.

Reanalysis datasets have many applications and are widely used as a source of data by decision makers (e.g. the insurance industry). Reanalyses are also used within the climate community, for example, to evaluate climate models (Vavrus 2013; Day et al. 2018). However, there are multiple reanalysis datasets available that use different models and data assimilation systems. This study has found some robust characteristics of Arctic storms. Generally, there is good agreement between the reanalysis datasets in the location, time and maximum $\mathrm{T} 42$ relative vorticity of the most intense Arctic storms. However, there are generally greater differences between the datasets in winter than in summer, which may be associated with the lower amount of observations that are assimilated into the datasets and the occurrence of conditions that are hard to represent in numerical models in winter. These differences in Arctic storm characteristics between reanalysis datasets may be reduced by special observing periods such as the Year of Polar Prediction (Jung et al. 2016), that may increase the amount of observations available for data assimilation or may lead to the improvement in the representation of Arctic conditions in numerical models. These differences may also be reduced in future reanalysis datasets, which may use more sophisticated data assimilation schemes.

Acknowledgements The authors acknowledge the funding and support from the Scenario NERC Doctoral Training Partnership Grant (NE/L002566/1) and co-sponsor, AXA XL, in the development of this research. The authors would also like to acknowledge the European Centre for Medium Range Forecasting (ECMWF) for the production of ERA-Interim reanalysis dataset, the Japan Meteorological Agency (JMA) for the production of the JRA-55 reanalysis dataset, the National Aeronautics Space Association (NASA) Goddard Earth Observing System (GOES) for the production of the MERRA-2 reanalysis dataset, and the National Oceanic and Atmospheric Administration (NOAA) National Centers for Environmental Prediction (NCEP) for the production of the NCEP-CFSR reanalysis dataset. The work described in this paper has received funding from the European Union's Horizon 2020 Research and Innovation programme through Grant agreement no. 727862 APPLICATE. The content of the article is the sole responsibility of the author(s) and it does not represent the opinion of the European Commission, and the Commission is not responsible for any use that might be made of information contained. Finally, we thank the anonymous reviewers for their constructive comments that helped to improve this manuscript.

Open Access This article is licensed under a Creative Commons Attribution 4.0 International License, which permits use, sharing, 
adaptation, distribution and reproduction in any medium or format, as long as you give appropriate credit to the original author(s) and the source, provide a link to the Creative Commons licence, and indicate if changes were made. The images or other third party material in this article are included in the article's Creative Commons licence, unless indicated otherwise in a credit line to the material. If material is not included in the article's Creative Commons licence and your intended use is not permitted by statutory regulation or exceeds the permitted use, you will need to obtain permission directly from the copyright holder. To view a copy of this licence, visit http://creativecommons .org/licenses/by/4.0/.

\section{References}

Bauer P, Magnusson L, Thépaut J-N, Hamill TM (2016) Aspects of ECMWF model performance in polar areas. Q J R Meteorol Soc 142(695):583-596

Blender R, Schubert M (2000) Cyclone tracking in different spatial and temporal resolutions. Mon Weather Rev 128(2):377-384

Crawford A, Serreze M (2015) A new look at the summer Arctic frontal zone. J Clim 28(2):737-754

Crawford AD, Serreze MC (2016) Does the summer Arctic frontal zone influence Arctic ocean cyclone activity? J Clim 29(13):4977-4993

Day JJ, Hodges KI (2018) Growing land-sea temperature contrast and the intensification of Arctic cyclones. Geophys Res Lett 45(8):3673-3681

Day JJ, Holland MM, Hodges KI (2018) Seasonal differences in the response of Arctic cyclones to climate change in CESM1. Clim Dyn 50(9-10):3885-3903

Dee DP et al (2011) The ERA-Interim reanalysis: configuration and performance of the data assimilation system. Q J R Meteorol Soc 137(656):553-597

Flake LE (2013) Navigating an ice-free Arctic: Russia's policy on the Northern Sea Route in an era of climate change. RUSI J 158(3):44-52

Gelaro R et al (2017) The modern-era retrospective analysis for research and applications, version 2 (MERRA-2). J Clim 30(14):5419-5454

Hodges K (1994) A general method for tracking analysis and its application to meteorological data. Mon Weather Rev 122(11):2573-2586

Hodges K (1995) Feature tracking on the unit sphere. Mon Weather Rev 123(12):3458-3465

Hodges K (1996) Spherical non-parametric estimators applied to the UGAMP model integration for AMIP. Mon. Weather Rev. 124(12):2914-2932

Hodges K (1999) Adaptive constraints for feature tracking. Mon Weather Rev 127(6):1362-1373

Hodges K (2008) Confidence intervals and significance tests for spherical data derived from feature tracking. Mon Weather Rev 136(5): 1758-1777

Hodges KI, Lee RW, Bengtsson L (2011) A comparison of extratropical cyclones in recent reanalyses ERA-Interim, NASA MERRA, NCEP CFSR, and JRA-25. J Clim 24(18):4888-4906

Hoskins BJ, Hodges KI (2002) New perspectives on the Northern Hemisphere winter storm tracks. J Atmos Sci 59(6):1041-1061

Jung $\mathrm{T}$ et al (2012) High-resolution global climate simulations with the ECMWF model in Project Athena: experimental design, model climate, and seasonal forecast skill. J Clim 25(9):3155-3172

Jung $\mathrm{T}$ et al (2016) Advancing polar prediction capabilities on daily to seasonal time scales. Bull Am Meteorol Soc 97(9):1631-1647

Kobayashi S et al (2015) The JRA-55 reanalysis: general specifications and basic characteristics. J Meteorol Soc Jpn 93(1):5-48
Lawrence H, Farnan J, Sandu I, Bormann N, Bauer P, Magnusson L (2019) An assessment of the use of observations in the Arctic at ECMWF. ECMWF Technical memorandum, 845. https://doi. org/10.21957/exlwb4o04. http://www.ecmwf.int/en/research/publi cations

Melia N, Haines K, Hawkins E (2016) Sea ice decline and 21st century trans-Arctic shipping routes. Geophys Res Lett 43(18):9720-9728

National Snow \& Ice Data Centre (2019) Sea ice index. https://nsidc .org/data/seaice_index. Accessed 4 Mar 2019

Neu U et al (2013) IMILAST: a community effort to inter-compare extratropical cyclone detection and tracking algorithms. Bull Am Meteorol Soc 94(4):529-547

Petrick S, Riemann-Campe K, Hoog S, Growitsch C, Schwind H, Gerdes R, Rehdanz K (2017) Climate change, future Arctic sea ice, and the competitiveness of European Arctic offshore oil and gas production on world markets. Ambio 46(3):410-422

Pinto JG, Spangehl T, Ulbrich U, Speth P (2005) Sensitivities of a cyclone detection and tracking algorithm: individual tracks and climatology. Meteorologische Zeitschrift 14(6):823-838

Pithan F et al (2016) Select strengths and biases of models in representing the Arctic winter boundary layer over sea ice: the Larcform 1 single column model intercomparison. J Adv Model Earth Syst 8(3):1345-1357

Reed RJ, Kunkel BA (1960) The Arctic circulation in summer. J Meteorol 17(5):489-506

Rudeva I, Gulev SK (2007) Climatology of cyclone size characteristics and their changes during the cyclone life cycle. Mon Weather Rev 135(7):2568-2587

Rudeva I, Gulev SK, Simmonds I, Tilinina N (2014) The sensitivity of characteristics of cyclone activity to identification procedures in tracking algorithms. Tellus A Dyn Meteorol Oceanogr 66(1):24-961

Saha $\mathrm{S}$ et al (2010) The NCEP climate forecast system reanalysis. Bull Am Meteorol Soc 91(8):1015-1058

Saha $\mathrm{S}$ et al (2014) The NCEP climate forecast system version 2. J Clim 27(6):2185-2208

Sandu I, Beljaars A, Bechtold P, Mauritsen T, Balsamo G (2013) Why is it so difficult to represent stably stratified conditions in numerical weather prediction (NWP) models? J Adv Model Earth Syst 5(2):117-133

Sepp M, Jaagus J (2011) Changes in the activity and tracks of Arctic cyclones. Clim Change 105(3-4):577-595

Serreze M C (1995) Climatological aspects of cyclone development and decay in the Arctic. Atmos Ocean 33(1):1-23

Serreze MC, Barrett AP (2008) The summer cyclone maximum over the central Arctic Ocean. J Clim 21(5):1048-1065

Serreze MC, Lynch AH, Clark MP (2001) The Arctic frontal zone as seen in the NCEP-NCAR reanalysis. J Clim 14(7):1550-1567

Simmonds I (2000) Size changes over the life of sea level cyclones in the NCEP reanalysis. Mon Weather Rev 128(12):4118-4125

Simmonds I, Burke C, Keay K (2008) Arctic climate change as manifest in cyclone behavior. J Clim 21(22):5777-5796

Sinclair MR (1994) An objective cyclone climatology for the Southern Hemisphere. Mon Weather Rev 122(10):2239-2256

Sorteberg A, Walsh J E (2008) Seasonal cyclone variability at 70。N and its impact on moisture transport into the Arctic. Tellus Ser A 60(3):570-586

Tilinina N, Gulev SK, Bromwich DH (2014) New view of arctic cyclone activity from the Arctic system reanalysis. Geophys Res Lett 41(5):1766-1772

Tous M, Zappa G, Romero R, Shaffrey L, Vidale P L (2016) Projected changes in medicanes in the hadgem 3 n512 high-resolution global climate model. Clim Dyn 47(5-6):1913-1924

Vavrus SJ (2013) Extreme Arctic cyclones in CMIP5 historical simulations. Geophys Res Lett 40(23):6208-6212 
Wang M, Overland J (2012) Summer Arctic sea ice will be gone sooner or later-an update from CMIP5 models. Geophys Res Lett 39(L18):501

Zahn M, Akperov M, Rinke A, Feser F, Mokhov I I (2018) Trends of cyclone characteristics in the Arctic and their patterns from different reanalysis data. J Geophys Res Atmos 123(5):2737-2751

Zappa G, Shaffrey L, Hodges K (2014) Can polar lows be objectively identified and tracked in the ECMWF operational analysis and the ERA-Interim reanalysis? Mon Weather Rev 142(8):2596-2608

Zappa G, Shaffrey LC, Hodges KI, Sansom PG, Stephenson DB (2013) A multimodel assessment of future projections of North Atlantic and European extratropical cyclones in the CMIP5 climate models. J Clim 26(16):5846-5862

Zhang X, Walsh JE, Zhang J, Bhatt US, Ikeda M (2004) Climatology and interannual variability of Arctic cyclone activity: 1948-2002. J Clim 17(12):2300-2317

Publisher's Note Springer Nature remains neutral with regard to jurisdictional claims in published maps and institutional affiliations. 